\title{
Pemanfaatan Bonggol Pisang Menjadi Stick Nugget Untuk Peningkatan Gizi Masyarakat Desa Soket Laok Tragah Kabupaten Bangkalan
}

\author{
Rakhmawati \\ Program Studi Teknologi Industri Pertanian Fakultas Pertanian \\ Universitas Trunojoyo Madura \\ E-mail : rakhma_ub@yahoo.co.id
}

DOI: http://dx.doi.org/10.21107/pgd.v5i1.5165

\begin{abstract}
Abstrak
Artikel Diterima : 5 Januari 2019/ Revisi : 3 Maret 2019/Terbit : 15 April 2019

Pohon pisang selama ini hanya dimanfaatkan pada buah dan daun pisangnya saja. Buah pisang diolah menjadi keripik pisang,sale pisang dan jajanan basah. Sedangkan daun pisang untuk pembungkus makanan. Bagian buah pisang yang lain masih jarang digunakan. Salah satu bagian pisang adalah bonggol pisang yang dapat diolah menjadi stick nugget dan olahan lainnya. Tujuan dari pemanfaatan bonggol pisang ini adalah (i) meningkatkan kesadaran masyarakat akan pemanfaatan bagian dari buah pisang yang selama ini belum dioptimal pemanfaatannya; (ii) mengenalkan olahan dari bonggol pisang (iii) meningkatkan gizi masyarakat soket laok untuk bidang pangan (iv) meningkatkan income/ pendapatan penduduk soket laok dengan membuka usaha nugget bonggol pisang. Lokasi pelaksanaan pengolahan produk stick nugget bonggol pisang ini adalah di desa Soket Laok Kecamatan Tragah. Secara umum pelaksanaan produk olahan bonggol pisang di Kabupaten Bangkalan dilakukan melalui beberapa tahapan, yaitu pendataan pohon pisang yang ada di wilayah Soket Laok terkait dengan jumlah/banyaknya bonggol pisang yang ada, persiapan bahan dan alat, pembukaan acara dan penjelasan materi dan diskusi kelompok serta kegiatan di lapangan. Pengolahan produk dan pungujian gizi di laboratorium universitas trunojoyo Madura (UTM). Hasil nugget bonggol pisang yang telah dibuat dilakukan pengujian menggunakan metode SNI 01-3553-3006. Setiap 1 gram nugget bonggol pisang mengandung 50,29\% kadar air, 6,19\% kadar abu, dan 23,63\% serat kasar. Seperti yang telah tercantum diatas, maka bonggol nugget pisang mempunyai khasiat untuk melancarkan pencernaan.
\end{abstract}

Kata Kunci : bonggol pisang, stick nugget, nilai gizi

\section{PENDAHULUAN}

Tanaman pisang adalah asli Asia Tenggara termasuk Indonesia dimana pisang termasuk famili Musaceae dari ordo Scitamainae dan terdiri dari dua genus, yaitu Musa dan Ensete. Genus Musa terbagi dalam empat golongan, yaitu Rhodochlamys, Callimusa, Australimusa dan Eumusa. Golongan Australimusa dan Eumusa merupakan jenis pisang yang dapat dikonsumsi, baik segar maupun olahan. Buah pisang yang dimakan segar sebagian besar berasal dari golongan Eumusa, yaitu Musa acuminata dan Musa balbisiana (Nuskha, 2012).

Pemanfaatan bagian tanaman pisang mulai dari akar sampai daun terutama yang banyak dikonsumsi masyarakat adalah buahnya. Sedangkan bagian tanaman pisang yang lain, yaitu jantung, batang, kulit buah, dan bonggol jarang dimanfaatkan dan dibuang begitu saja menjadi limbah pisang. Bonggol pisang adalah bagian bawah batang pisang yang mengembung seperti umbi. Menurut Suyanti dan Supriyadi
(2008) dalam Damiati et.al (2014), bonggol pisang merupakan tanaman berupa umbi batang (batang aslinya).

Pisang merupakan salah satu komoditas holtikultura yang melimpah di Kabupaten Bangkalan. Hasil pertanian holtikultura yang mempunyai nama latin Musa paradisiaca hampir dapat dijumpai di setiap kecamatan di Kabupaten Bangkalan. Pada Tahun 2012 produksi pisang di Kabupaten Bangkalan, menurut BPS Kabupaten Bangkalan pisang menduduki urutan sepuluh besar dalam menghasilkan total tanaman pangandengan hasil produksi 185.568 kwintal dari pada hasil holtikultura lainnya seperti, durian, mangga, jambu biji, belimbing dll (BPS Kabupaten Bangkalan, 2012).

Pada tahun 2015 produksi pisang di Kabupaten Bangkalan mencapai 6.802 ton pisang (BPS Kabupaten Bangkalan 2016). Angka produksi pisang yang mencapai 6.802 ton, menunjukan potensi dari buah pisang yang 
besar. Tanaman pisang memiliki banyak manfaat dari daun sampai dengan akarnya, terutama yang banyak di konsumsi dan dimanfaatkan adalah buahnya. Sedangkan bagaian yang lain seperti daun, kulit buah, batang, jatung dan bonggolnya jarang sekali di manfaatkan. Pada bonggol pisang memiliki kandungan gizi yang cukup tinggi, kandungan gizi yang dimiliki bonggol pisang adalah karbohidrat $(66,2 \%)$, protein, air, dan mineralmineral penting lainnya (Wulandari et al 2009).

Masyarakat Soket Laok memanfaatkan lahan sebagai ladang berternak dan berkebun. Mayoritas masyarakat Soket Laok mengolah lahan sebagai tempat berternak ayam, bebek, kambing, maupun sapi. Akan tetapi tidak jarang masyarakat memanfaatkan lahannya untuk berkebun, seperti tanaman obat keluarga. Masyarakat Soket Laok khususnya di dusun Gundul memanfaatkan lahannya untuk ditanami pisang, temulawak, temu hitam, dan temuputih.

Masyarakat Soket Laok khususnya di dusun Gundul biasanya menanam pisang di depan atau di pojok tanah rumahnya. Cara menanam tanaman pisang dapat ditanam dari tunas. Biasanya langkah-langkah yang dilakukan adalah:

1. Mencari bibit pisang yang sesuai.

2. Mempersiapkan lahan sebagai media tanam tunas pisang.

3. Memindahkan tunas pisang yang sudah disiapkan untuk ditanam di lubang tanam.

4. Memelihara tanaman hingga masa panen tiba.

5. Memanen buah pisang jika buah sudah berubah menjadi warna hijau tua atau kekuning kuningan.

Tabel 1. Komposisi Kimia Pisang

\begin{tabular}{ll}
\hline Kandungan & Kadar (\%) \\
\hline Karbohidrat & 76,57 \\
Air & 18,97 \\
Lemak & 2,11 \\
Protein & 0,32 \\
Kalsium & $717 \mathrm{mg} / 100 \mathrm{~g}$ \\
Fosfor & $114 \mathrm{mg} / 100 \mathrm{~g}$ \\
Besi & $0,13 \mathrm{mg} / 100 \mathrm{~g}$
\end{tabular}

Sumber : Kementerian Kesehatan, 2015

Bonggol Pisang mengandung energi sebesar 43 kilokalori, protein 0,6 gram, karbohidrat 11,6 gram, lemak 0 gram, kalsium 15 miligram, fosfor 60 miligram, dan zat besi 1 miligram.
Selain itu di dalam Bonggol Pisang juga terkandung vitamin A sebanyak 0 IU, vitamin B1 0,01 miligram dan vitamin C 12 miligram. Hasil tersebut didapat dari melakukan penelitian terhadap 100 gram Bonggol Pisang, dengan jumlah yang dapat dimakan sebanyak $100 \%$.

Nugget merupakan produk olahan restrukturisasi, yaitu teknik pengolahan dengan memanfaatkan potongan daging yang berukuran relatif kecil dan tidak beraturan, kemudian dilekatkan kembali menjadi ukuran yang lebih besar. Proses pengolahan nugget meliputi penggilingan bahan baku, penambahan bahan pengisi dan bumbu, pengukusan, pencetakan, pemotongan, pelapisan basah dengan adonan tepung dan air (batter), pelapisan kering dengan tepung roti (breader) lalu digoreng. Nugget dapat digoreng matang maupun setengah matang. Penggorengan nugget setengah matang harus dilanjutkan dengan proses pembekuan untuk mempertahankan mutu nugget selama penyimpanan. Nugget yang baik memiliki tekstur bagian dalam yang kompak, saling melekat dan juicy serta tekstur bagian luar yang renyah dan kering. Untuk kandungan gizi dari nugget nabati sangat berbeda dengan nugget hewani adapaun kandungan gizi dari nugget nabati dapat disimak dari tabel 2 dibawah ini:

Tabel 2. Kandungan Gizi Nugget Nabati

\begin{tabular}{|c|c|c|c|}
\hline NO & KRITERIAUUI & SATUAN & PERSYARATAN \\
\hline \multirow[t]{4}{*}{1.} & Keadaan & 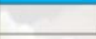 & \\
\hline & 1.1. Bau & - & normal, khas \\
\hline & 1.2. Warna & - & normal \\
\hline & 1.3. Rasa & - & normal \\
\hline 2. & Kadar Air (b/b) & $\%$ & Maks. 65 \\
\hline 3. & Kadar Abu (b/b) & $\%$ & Maks. 1,5 \\
\hline 4. & Kadar Lemak (b/b) & $\%$ & Min. 10 \\
\hline 5. & Kadar Protein $(\mathrm{N} \times 6,25)(\mathrm{b} / \mathrm{b})$ & $\%$ & Min. 16 \\
\hline 6. & Kadar serat kasar $(\mathrm{b} / \mathrm{b})$ & $\%$ & Maks. 2,5 \\
\hline \multirow[t]{5}{*}{7.} & Cemaran logam & & \\
\hline & 7.1. Kadmium (Cd) & $\mathrm{mg} / \mathrm{kg}$ & Maks. 0,2 \\
\hline & 7.2. Timbal $(\mathrm{Pb})$ & $\mathrm{mg} / \mathrm{kg}$ & Maks. 0,25 \\
\hline & 7.3. Timah (Sn) & $\mathrm{mg} / \mathrm{kg}$ & Maks. 40 \\
\hline & 7.4. Merkuri $(\mathrm{Hg})$ & $\mathrm{mg} / \mathrm{kg}$ & Maks. 0,03 \\
\hline 8. & Cemaran arsen (As) & $\mathrm{mg} / \mathrm{kg}$ & Maks. 0,25 \\
\hline \multirow[t]{3}{*}{9.} & Cemaran mikroba & & \\
\hline & 9.1. Bakteri coliform & APM $/ g$ & Maks. 10 \\
\hline & 9.2. Salmonella sp. & - & Negatif/25 g \\
\hline
\end{tabular}

Sumber : Syarat Mutu Nugget Nabati (SNI 3144: 2009)

Nugget yang sering dijumpai di masyarakat adalah nugget berbahan hewani, diantaranya daging ayam dan daging sapi. Bahan hewani ini menyebabkan nugget tidak dapat dikonsumsi oleh kalangan vegetarian. Oleh karena itu, perlu dilakukan penggantian bahan hewani dengan bahan nabati. Salah satu bahan nabati yang dapat digunakan dalam pembuatan nugget adalah bonggol pisang. 
Nugget bonggol pisang adalah nugget yang menjadikan bonggol pisang sebagai bahan dasar olahannya. Berbeda sama nugget daging yang mungkin biasa di makan, nugget bonggol pisang ini punya cita rasa yang beda dan unik. Bonggol pisang yang selama ini di kira sampah ternyata bisa dimanfaatkan buat jadi bahan makanan, salah satunya ya jadi nugget ini. Nugget bonggol pisang ini mengandung zat-zat bermanfaat yang diperlukan oleh tubuh. Kandungan gizinya yang lengkap seperti tanin, sapomin, flavonoid, serotonin, neropinefrin, hidroksitriptamin, dopamine, vitamin, A, vitamin, B, vitamin C dan serat bisa berfungsi sebagai obat, meningkatkan kekebalan tubuh, dan sebagai antiseptik.Tujuan dari pemanfaatan bonggol pisang ini adalah :

a. Meningkatkan kesadaran masyarakat dan membina masyarakat untuk mengetahui manfaat dari bonggol pisang yang selama ini tidak terpakai menjadi zero waste.

b. Membantu masyarakat dalam meningkatkan pendapatan dengan melihat nilai ekonomis pada bonggol pisang.

c. Memberikan pengetahuan tentang gizi bonggol pisang.

\section{METODE}

Pelaksanaan kegiatan pengabdian masyarakat dalam bentuk penyuluhan dan demo pembuatan nugget bonggol pisang di Desa Soket Laok dilakukan dengan langkah-langkah sebagai berikut:

\section{Tahap Persiapan}

- Persiapan alat- alat: pisau, sendok, baskom, telenan, blender, kompor dan wajan.

- Pengadaan bahan: bonggol pisang, tepung maizena, air, bumbu dapur, garam.

- Pengolahan nungget bonggol pisang.

- Pengemasan dan pelabelan nugget bonggol pisang.

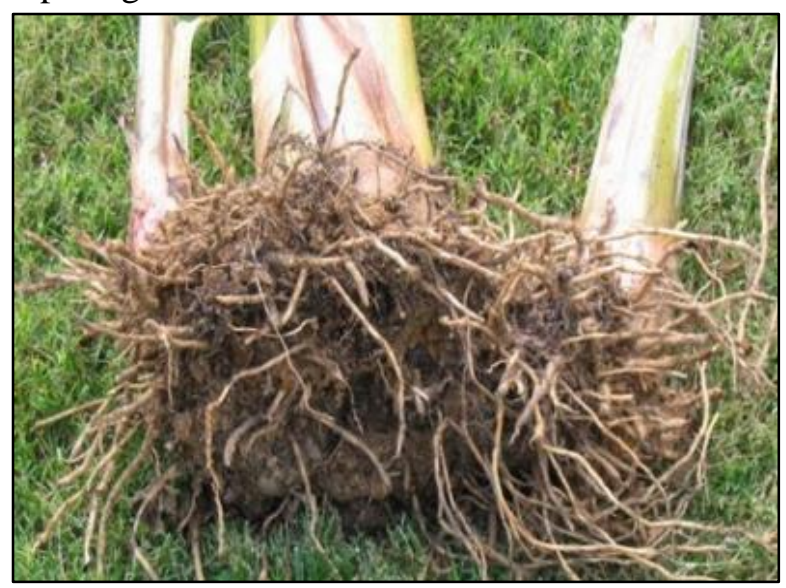

Gambar 1. Bonggol Pisang Sebagai Bahan Dasar Pembuatan Nugget

\section{Tahap Pelaksanaan}

- Menentukan peserta pelatihan pembuatan nugget

- Pengolahan bonggol pisang dan diskusi dengan masysrakat tentang diversifikasi bonggol pisang yang akan digunakan yang memprioritaskan jenis pisang yang favorit dan paling banyak di lokasi setempat.
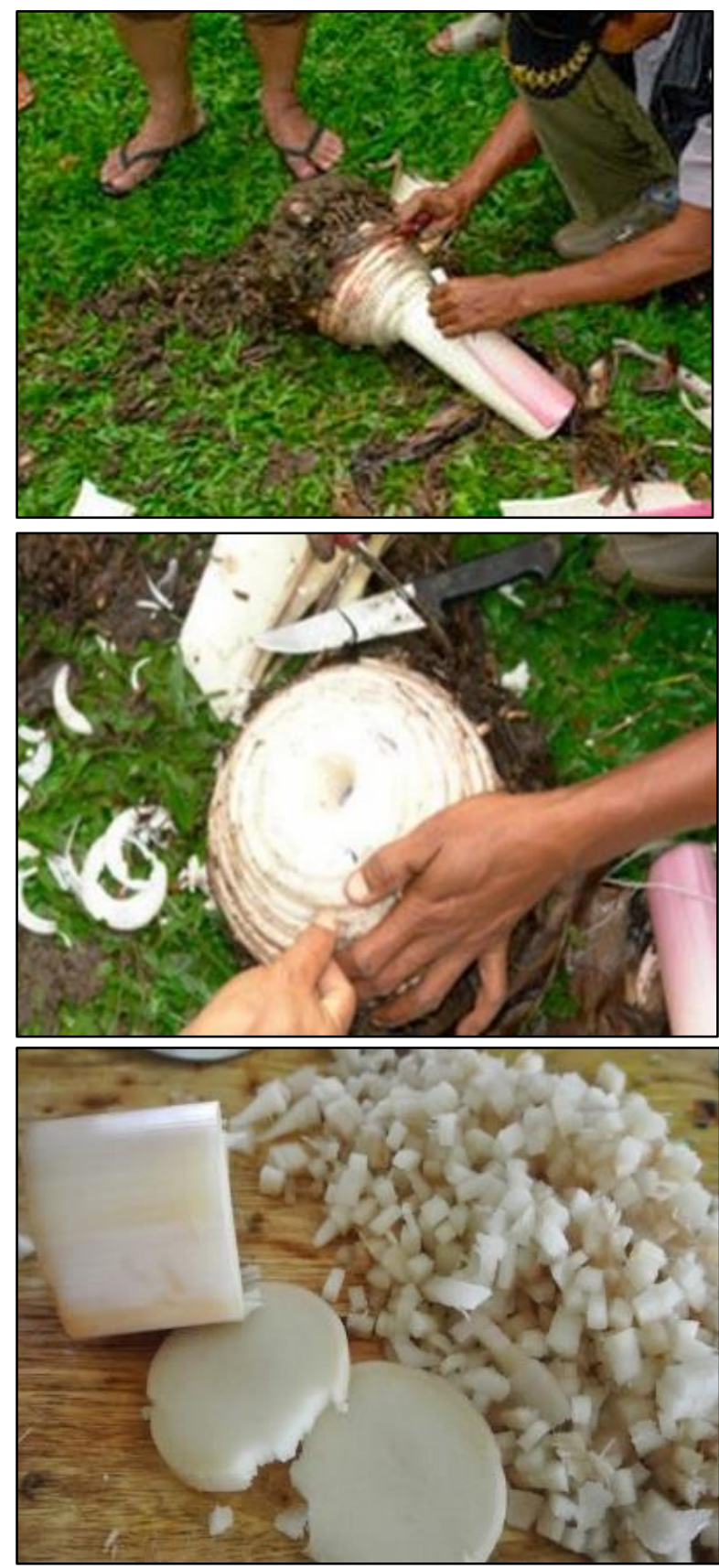

Gambar 2. Pengolahan Bonggol Pisang (Pembersihan, Pengupasan dan Pemotongan)

\section{Tahapan Monev dan Pelaporan}

- Pekerjaan monev dilakukan setelah selesai melakukan pelatihan nugget dari kelompok masyarakat yang tertunjuk dan menentukan 
jenis bonggolnya yang paling banyak ada di desanya.

- Penyusunan laporan kegiatan

\section{HASIL DAN PEMBAHASAN Diversifikasi Pangan}

Secara definitif, menurut Undang-undang RI Nomor 18 tahun 2012 pangan adalah segala sesuatu yang berasal dari sumber hayati produk pertanian, perkebunan, kehutanan, perikanan, peternakan, perairan dan air, baik yang diolah maupun tidak diolah yang diperuntukkan sebagai makanan atau minuman bagi konsumsi manusia, termasuk di dalamnya adalah Bahan Tambahan Pangan (BTP). Menurut Budiyanto (2004) pangan adalah bahan-bahan yang dimakan sehari-hari untuk memenuhi kebutuhan energi bagi pemeliharaan, pertumbuhan, kerja dan penggantian jaringan tubuh yang rusak.Pangan juga dapat diartikan sebagai bahan sumber gizi dan merupakan kebutuhan manusia yang paling asasi atau kebutuhan pokok (basic need).

Mengenai pangan yang penting untuk memenuhi kebutuhan pokok kehidupan manusia, karena semakin besar jumlah anggota suatu keluarga akan semakin banyak mengkonsumsi bahan pangan dan makanan. Oleh karena itu perlu adanya diversifikasi pangan yang merupakan pilihan masyarakat dalam kegiatan konsumsi sesuai dengan citra rasa yang diinginkan dan menghindari kebosanan untuk mendapatkan pangan dan gizi agar hidup sehat dan aktif.Hal ini memang sangat dipengaruhi oleh daya beli masyarakat, pengetahuan, ketersediaan, dukungan kebijakan dan faktor sosial budaya.Secara implisit, upaya diversifikasi konsumsi pangan dapat diidentifikasi dengan upaya perbaikan gizi untuk mendapatkan kualitas sumberdaya manusia Indonesia yang mampu berdaya saing dengan negara-negara lain (Ariani, 2012).

Diversifikasi pangan menjadi salah satu pilar utama dalam mewujudkan ketahanan pangan. Diversifikasi konsumsi pangan tidak hanya sebagai upaya mengurangi ketergantungan pada beras tetapi juga upaya peningkatan perbaikan gizi untuk mendapatkan manusia yang berkualitas dan mampu berdaya saing dalam percaturan globalisasi (Himagizi, 2009). Melihat banyaknya bonggol pisang yang kurang dimanfaatkan yang ada hanya dibiarkan saja setelah memanen buah pisangnyamaka pelatihan pengolahan bonggol pisang ini di Soket Laok Tragah Bangkalan mengikutsertakan puluhan ibu-ibu mempelajari bagaimana produk olahan bonggol pisang sebagai alternative diversifikasi makanan yang selama ini belum dimanfaatkan sama sekali. Inovasi ini juga diharapkan mampu meningkatkan perekonomian masyarakat di Desa Soket Laok dengan cara memasarkannya di sekitar Suramadu.
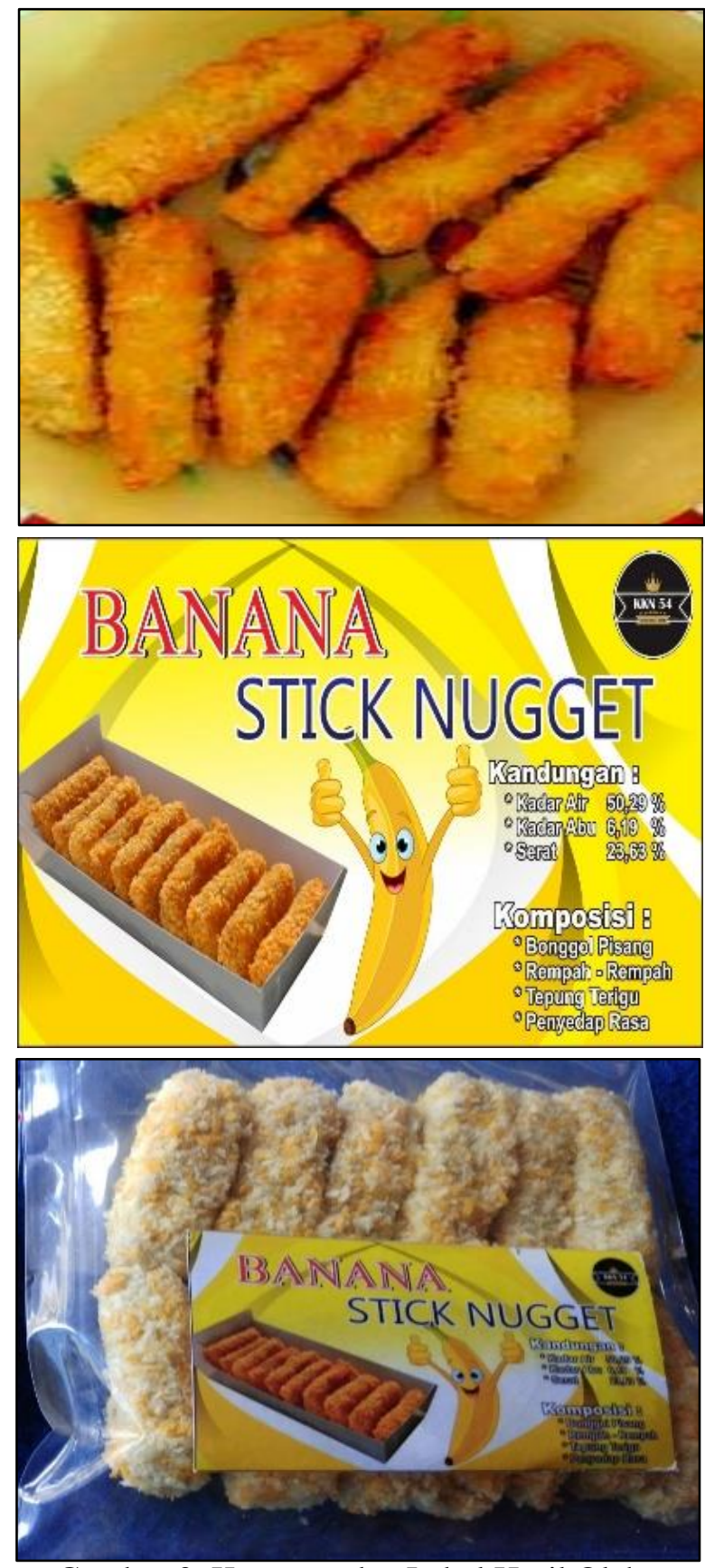

Gambar 3. Kemasan dan Label Hasil Olahan Nugget Bonggol Pisang

Hal ini menjadi penyemangat dari ibu-ibu dan pemuda desa untuk memiliki semangat agar dapat melakukan inovasi produk yang nantinya bisa menopang perekonomian di Desa Soket Laok dan sukur sukur mampu menjadi salah satu contoh di Kabupaten Bangkalan pada umumnya. Lebih jauh lagi nantinya, tidak hanya sekedar mampu berkreasi dengan bonggol pisang, kedepan juga 
akan terus digencarkan program agar produk olahan ini dapatt menjadi tambahan penghasilan warga dengan memanfaatkan arus lalu lintas Suramadu yang sangat luar biasa banyak agar Tragah menjadi salah satu wilayah Bangkalan yang dapat dilirik dengan produk unik dan inovatifnya sebagai penghasil produk olahan bonggol pisang.

\section{Nugget Bonggol Pisang}

Menurut Yuliani (2013), Bonggol Pisang yang berlimpah di berbagai pelososok daerah dan Indonesia pada umumnya belum dioptimalkan pemanfaatannya karena kandungan gizinya masih cukup tinggi, terutama kandungan protein dan serat kasar yang bermanfaat bagi kesehatan. Oleh karena itu, bonggol pisang perlu dimanfaatkan menjadi prduk olahan lainnya seperti nugget dll yang sangat diminati masyarakat dari semua kalangan, baik anak kecil, dewasa maupun orang tua yang lebih menarik untuk disajikan dan praktis.

Bahan pembantu untuk membuat nugget meliputi bawang putih, garam, merica, telur, tepung tapioka dan tepung roti (Mushollaeni dan Tirtosastro, 2007). Sedangkan, peralatan yang digunakan antara lain: baskom, plastik, sendok, blender, kompor, timbangan, pisau, cutting board atau talenan, dan dandang (Yuliani, 2013). Proses pembuatan nugget ini meliputi beberapa tahap yaitu tahap persiapan, tahap pelaksanaan dan tahap penyelesaian.

Tahap persiapan merupakan langkah awal untuk membuat nugget iniyang meliputi persiapan alat dan persiapan bahan. Alat untuk proses pembuatan yaitu baskom plastik, sendok, blender, kompor, pisau, cutting board atau talenan, dan dandang. Sedangkan alat ukur yang digunakan berupa timbangan digital yang dapat dipertanggungjawabkan kebenaran hasilnya. Bahan yang digunakan harus berkualitas bagus dan ditimbang sesuai dengan takaran resep nugget untuk menghindari kesalahan (Yuliani, 2013).

Tahap pelaksanaan pembuatan nugget ini meliputi tahap penimbangan bahan, penggilingan untuk memudahkan pencampuran bahan, pencetakan yang dilakukan dengan cara dibungkus dengan plastik bulat panjang dengan diameter $2 \mathrm{~cm}$ dan bagian tepinya diikat, pengukusan selama 30 menit, selanjutnya proses pemaniran yang dilakukan melalui dua tahap yaitu pencelupan nugget yang sudah dipotong pada putih telur dan pelumuran tepung roti, penggorengan, dan pembekuan agar produk tahan lama. Tahap penyelesaian yaitu nugget yang sudah digoreng dan didinginkan kemudian dikemas dengan plastik yang ditutup rapat dengan sealer kemudian diletakkan dalam freezer agar tidak mudah rusak (Yuliani, 2013)

Bonggol pisang adalah salah satu pilihan yang tepat untuk pengganti beras sebagai makanan pokok. Karena kandungan bonggol pisang kaya akan karbohidrat dan serat yang tinggi. Sebagian besar masyarakat menganggap bonggol pisang sebagai sesuatu yang tidak berguna (limbah), di balik itu manfaatnnya bagi tubuh manusia cukup baik, disamping mengandung karbihidrat dan serat juga sebagai sumber energi, protein, lemak dan sebagaianya.

Bonggol Pisang yang bagian dari tanaman pisang yang sangat kurang dimanfaatkan (umbi pisang) dan apabila dibiarkan begitu saja akan menjadi limbah pertanian yang tidak bermanfaat (Sunarjo, 2003 dalam Hermawan, 2012). Bonggol pisang adalah pangkal batang yang berbentuk bulat dan besar.Bonggol pisang dibedakan atas dua macam, yaitu batang asli yang disebut bonggol (corn) dan batang palsu atau batang semu.Bonggol (corm) terletak dibawah permukaan tanah dan mempunyai beberapa mata (pink eye) yang tersusun dari pelepah daun yang saling menutupi, tumbuh tegak dan kokoh diatas permukaan tanah (Rukmana, 1999). Dari bonggol batang ini, tumbuh perakaran yang berfungsi seperti perakaran individu baru. Di bagian tersebut tumbuh suatu tonjolan dengan titik tumbuh baru (Suhardiman, 1997).

Bonggol merupakan sifat khas rhizoma dari tanaman monocotyedonael yang dapat menumbuhkan anakan baru. Bila rhizoma dibelah dari atas ke bawah terlihat bagian paling tengah yang disebut central cylinder, sedangkan lapiasn luarnya disebut cortex. Bagian di atasnya merupakan tempat tumbuh batang yang terdiri dari pelepah-pelepah (Munadjim, 2006). Bonggol pisang mengandung karbohidrat $(66,2 \%)$ dengan kadar air $(20 \%)$, mineral dan vitamin. Karbohidrat dalam bonggol pisang terutama berupa serat (Munadjim, 2006).

Untuk produktivitas bonggol pisang, jika diratarata berat bonggol pisang tiap pohonnya adalah 10 $\mathrm{kg}$ dan diasumsikan berat satu tandan pisang 15 $\mathrm{kg}$, maka dapat dihitung produktivitas bonggol pisang 37,89 ton/ha (Hermawan, 2012). Dengan jumlah produktivitas dari bonggol pisang tersebut dengan tingginya kandungan gizi yang terdapat didalam bonggol pisang, maka perlu ditingkatkan pemanfaatan bonggol pisang untuk diolah menjadi bahan baku pangan yang memiliki gizi tinggi. 
Pada saat panen bonggol pisang dari pohon pisang terdapat penanganan khusus, agar hasil bonggol pisang yang dipanen tidak mempengaruhi kualitas dari bonggol pisang tersebut.Penanganan pascapanen merupakan tahapan kegiatan yang dilakukan pada saat setelah panen agar hasil pertanian siap dan aman digunakan oleh konsumen dan atau diolah lebih lanjut oleh industri. Pada saat panen terdapat faktor yang mempengaruhi kualitas bonggol pisang yaitu pada saat penebangan pohon pisang lebih baik bonggol pisangnya juga ditebang kemudian langsung diambil untuk diolah jangan dibiarkan di tanah karena tanpa penanganan yang cepat, umbiumbian tersebut akan memburuk keadaannya apabila dibiarkan selama 3 hari, hal tersebut akan menjadikan perubahan warna pada bonggol pisang yang disebut dengan sistem respirasi pada umbi tersebut. Respirasi tersebut adalah menyebabkan berkurangnya cadangan makanan (dalam bentuk pati, gula, dan lain-lain) dalam komoditas, mengurangi rasa dari komoditas (terasa hambar) dan memacu pembusukkan (Kartasapoetra, 2001). Oleh karena itu penyimpanan setelah panen dapat mempengaruhi kualitas dari bonggol pisang tersebut.

Tabel 3. Kandungan Gizi Bonggol Pisang

\section{No Kandungan gizi Bongol basah Bonggol kering}

\begin{tabular}{llcc}
\hline 1 & Kalori (g) & 43.00 & 245.00 \\
2 & Protein (g) & 0.36 & 3.40 \\
3 & Lemak (g) & 0.00 & 0.00 \\
4 & Karbohidrat (g) & 11.60 & 66.20 \\
5 & Kalsium (mg) & 15.00 & 60.00 \\
6 & Fosfor (mg) & 60.00 & 150.00 \\
7 & Zat besi (mg) & 0.50 & 2.00 \\
8 & Vitamin A (SI) & 0.00 & 0.00 \\
9 & Vitamin B1 (mg) & 0.01 & 0.04 \\
10 & Vitamin C (mg) & 12.00 & 4.00 \\
11 & Air (g) & 86.00 & 20.00 \\
& Bagian yang dapat & & \\
12 & dimakan (\%) & 100.00 & 100.00 \\
\hline
\end{tabular}

Sumber : Direktorat Gizi, Depkes RI (1981) dalam Elisabeth (2013)

\section{$\underline{\text { Analisis Finansial }}$}

Bahan baku utama proses produksi stick nugget bonggol pisang adalah bonggol pisang yang berasal dari bagian pohon pisang dari pohon pisang di desa soket laok kecamatan tragah Bangkalan. Pengolahan nugget bonggol pisang juga menggunakan bahan penunjang seperti tepung tapioka, garam, merica, bawang putih, bawang merah, telur dan tepung roti. Rincian biaya untuk kebutuhan bahan baku penunjang produksi nugget bonggol pisang dapat dilihat pada Tabel 4. Total biaya bahan baku yang dibutuhkan sekali produksi sebesar Rp 1.159.100. Berdasarkan aspek finansial, nugget bonggol pisang dengan harga jual Rp 5.000 per 250 gram kemasan.

Tabel 4. Rincian Kebutuhan Bahan Baku Nugget Bonggol Pisang/hari

\begin{tabular}{lccr}
\hline Bahan Baku & Jumlah $(\mathbf{k g})$ & Total & \\
\hline Bongol pisang & 50 & $\mathrm{Rp}$ & 12.500 \\
Tapioka & 7,5 & $\mathrm{Rp}$ & 37.500 \\
Bawang putih & 2 & $\mathrm{Rp}$ & 58.000 \\
Bawang merah & 8 & $\mathrm{Rp}$ & 264.000 \\
Garam & 0,8 & $\mathrm{Rp}$ & 1.600 \\
Merica & 0,4 & $\mathrm{Rp}$ & 68.000 \\
Telur & 12,5 & $\mathrm{Rp}$ & 262.500 \\
Tepung roti & 15 & $\mathrm{Rp}$ & 135.000 \\
Kemasan & 400 & $\mathrm{Rp}$ & 320.000 \\
\hline Total & & $\mathrm{Rp}$ & 1.159 .100 \\
\hline
\end{tabular}
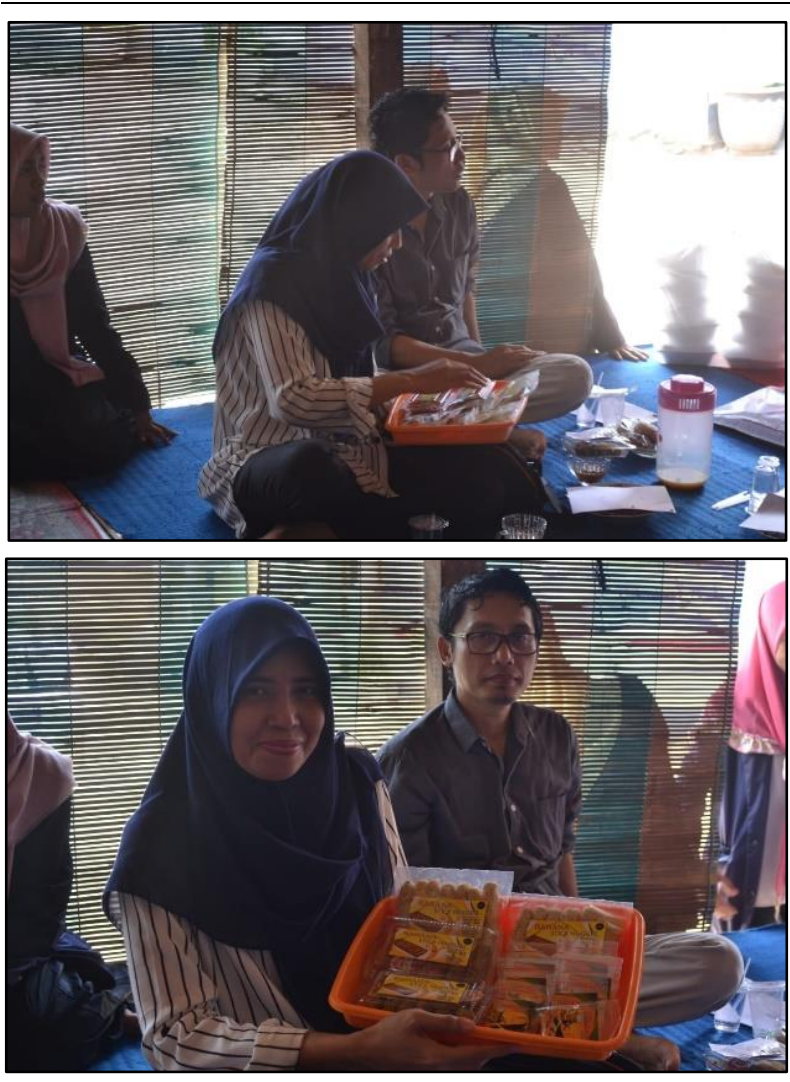

Gambar 4. Nugget Bonggol Pisang Siap Dipasarkan

Pada pengemasan dan pelabelan produk terdapat dua macam varian yaitu stick nugget bonggol pisang dalam bentuk frozen food dan siap saji. Dalam bentuk frozen konsumen dapat menyimpan lebih lama pada suhu rendah. Akan tetapi untuk pembeli yang pingin langsung menyantap bisa membeli dalam bentuk stick 
nugget yang sudah digoreng. Harga kemasan nugget Rp 5.000,- sangat terjangkau oleh pembeli melihat selama ini kemasan nugget hewani lebih mahal dengan kandungan gizi yang relatif hampir sama.
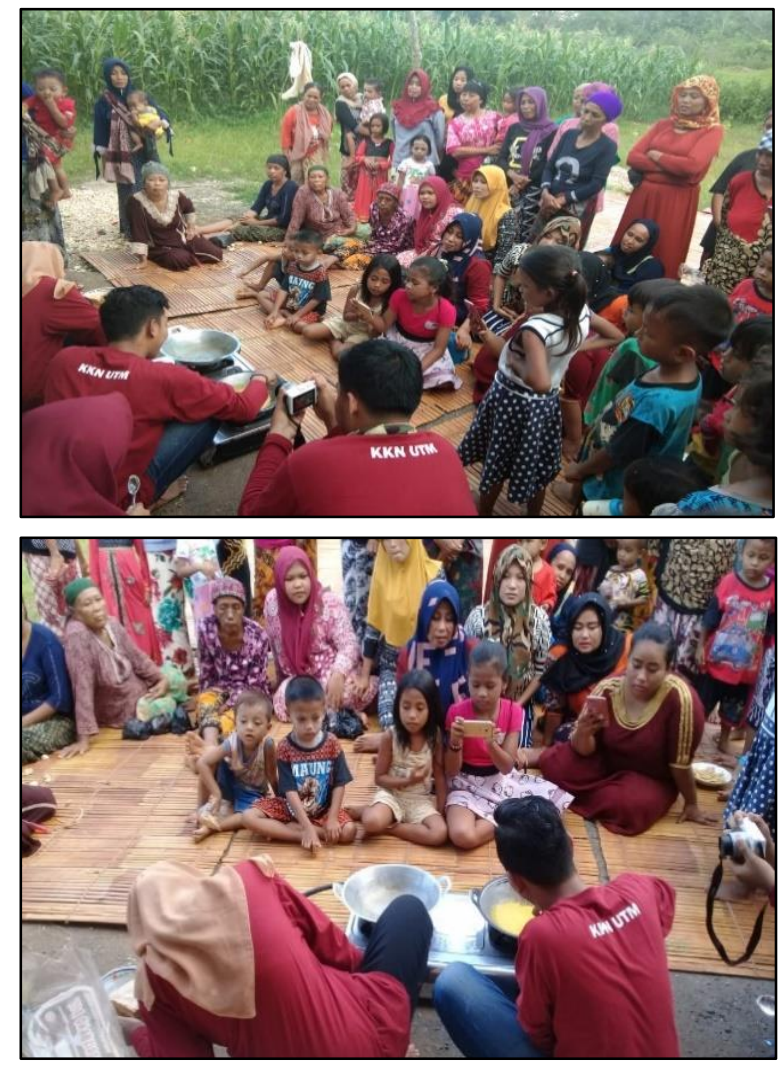

Gambar 5. Demo dan Sosialisasi Pengolahan Nugget Bonggol Pisang oleh Mahasiswa KKN

\section{KESIMPULAN}

Pelaksanaan kegiatan pengolahan stick nugget bonggol pisang di desa soket laok kecamatan tragah Kabupaten Bangkalan dilakukan pada tanggal 10-15 Januari 2019. Secara umum pelaksanaan pengolahan stick nugget bonggol pisang di soket laok berlangsung dengan baik, dilakukan melalui beberapa tahapan, yaitu pendataan jumlah bonggol pisang, persiapan bahan dan alat, pembukaan acara dan penjelasan, penyajian materi dan diskusi kelompok serta kegiatan di lapang.

Pelaksanaan demo pengolahan diikuti warga setempat dengan peserta sekitar 20 orang. Peserta terdiri dari warga sekitar yang berprofesi sebagai petani, ibu-ibu pedagang, anggota pemuda karang taruna dan perangkat desa. Kegiatan demo produk nugget bonggol pisang dilanjuti dengan analisis mutu di laboratorium UTM serta analisis perhitungan harga jual nugget bonggol pisang.

\section{DAFTAR PUSTAKA}

Agus, K.B. 2004. Mikrobiologi Terapan. Teknologi, Nutrisi, dan Keamanan Pangan. Jakarta

Badan Pusat Statistik. 2017. Luas Lahan Sawah Indonesia. Jakarta: Badan Pusat Statistik.

Badan Pusat Statistik. 2016. Kabupaten Bangkalan Dalam Angka 2016. Bangkalan. BPS Kabupaten Bangkalan.

Hardjowigeno, S dan Widiatmaka. 2001. Kesesuaian Lahan dan Perencanaan Tataguna Lahan. Fakultas Pertanian IPB. Bogor.

Hermawan, D. 2002. Studi Pembuatan Roti dengan Subtitusi Tepung Pisang Kepok. Fakultas Pertanian IPB. Bogor.

Kasmir dan Jakfar. 2010. Studi Kelayakan Bisnis: Edisi Kedua. Jakarta: Penerbit Prenada Media Group.

Kartasapoetra, A. G. 1994. Teknologi Penanganan Pasca. Panen. Pengaruh Tingkat Kematangan dan Lama Penyimpanan. Terhadap Mutu. Rineka Cipta

Mushollaeni dan Tirtosastro. 2007 Peningkatkan Produk Olahan Bonggol Pisang. Jurnal Teknologi Pertanian. Vol 5 No 2.

Putri, T.K; D Veronika; A. Ismail; A. Karuniawan; Y. Maxiselly; A. W. Irwan; W. Sutari. 2015. Pemanfaatan Jenis-Jenis Pisang (Banana Dan Plantain) Lokal Jawa Barat Berbasis Produk Sale dan Tepung. Jurnal Kultivasi. Vol. 14 No.2.

Rahmawati, D. 2015. Saluran Pemasaran Penjualan Nugget di PT Kepurun Pawana Indonesia, Klaten, Jawa Tengah. Tugas Akhir. Yogyakarta: Universitas Gadjah Mada

Sinukaban, N. 1989. Dasar-dasar Konservasi Tanah dan Perencanaan Pertanian Konservasi. Jurusan Ilmu Tanah. IPB. Bogor. 
Rakhmawati Pemanfaatan Bonggol Pisang 